\title{
Rhetorical Strategies of Alterity in Arthur Leared's Morocco and the Moors (1876) and Budgett Meakin's Life in Morocco (1905)
}

\author{
Lahoucine Aammari
}

University of Sultan Moulay Slimane, Beni-Mellal, Morocco

Arthur Leared's Morocco and the Moors (1876) and Budgett Meakin's Life in Morocco and Glimpses Beyond (1905) are two less-examined imperial travel texts on precolonial Morocco. These two travelogues are British (Irish and English, respectively) - a fact that casts on them from the beginning the special taste of this genre which is a British specialty par excellence. Coming from the same political and cultural backdrops, Leared and Meakin peregrinated into Morocco in a precolonial time when it was still perceived as the "Lands of the Moors". These two travellers responded to moments of interactions with the Moors as a culturally, socially and religiously different other. Both these Victorian travellers were aware of the fact of empire as their travelogues function as fodder to energize the discursive grandiloquence of empire. They stress an ethnocentric view in depicting Moroccans and their culture, and they communicate their observations through an interpretative framework, or in Foucauldian terminology, through the "discourses" provided by their culture. This paper undertakes the examination of these two travellers' perception of otherness; the approach is to question and bring to the fore the rhetorical and discursive strategies as well as modes of representation Leared and Meakin deploy in their encounters with the Moors in Pre-Protectorate Morocco.

Keywords

Alterity; Travel Writing; Self; Other; Modes of Representation; Arthur Leared; Budgett Meakin

\section{Introduction}

The last decades of the $20^{\text {th }}$ century and the outset of the $21^{\text {st }}$ century have undeniably witnessed a boom in travel writing as an interdisciplinary and 
nascent genre because the latter has been taken seriously in universities only in the past three or four decades, but this boom will surely not subside in the future. Because it is undertheorized, travel writing has seen a myriad of controversies concerning its definition. Right after the 1950s, which coincided with the rise of postcolonial theory, this genre "was usually dismissed by literary critics and cultural commentators as a minor, somewhat middlebrow form" (Thompson 2). In spite of this criticism, the genre has proven outstandingly immune and it has become one of the most popular and widely read forms of literature today. The growth in travel writing was caused by its paradigmatic reflection on the human (post)modern condition in the 1950s and afterwards. Post-modern theorists have directed their attention to travel "for its expression of the themes and condition of exile, migration, nomadism, and boundary-crossings" (Youngs v). Under such circumstances, travel writing has acquired a new relevance and prestige as a genre that can provide important insights into the often fraught encounters and exchanges currently taking place between cultures, and into the lives being led, and the subjectivities being formed and the identities being negotiated, in a globalizing world.

Travel accounts often clarify the mental maps that individuals and cultures have of the world and its inhabitants, and the larger matrix of prejudices, fantasies and assumptions that they bring to bear on any encounter with, or description of, the other. In this regard, in the late decades of the $19^{\text {th }}$ century and the outset of the twentieth century - the era of "high imperialism" most British travelogues deploy different tropes and conventions of colonial discourse to represent and often downplay other peoples, and to underpin the British Empire and its ideological pomposity.

One of the reasons behind the choice of these two travellers is that a perusal of British travellers to Morocco from the second half of the $19^{\text {th }}$ century to the outset of the $2 \mathrm{O}^{\text {th }}$ century, to the year 1912 , which coincided with the installation of the French Protectorate in Morocco, has brought to the fore the premise that there are two categories of British travellers. First, there are the travellers who see that the British should intervene soon to colonize and dominate the primitive and fanatic Moorish other. The second category of travellers is those traveller-writers who endorse the British policy which perceives that since its different interests are sustained, it would be better to keep the status quo and from time to time the British should prod Morocco on the march of history and "spur" it to take some reforms that would not go against general British policy in the country and to make the reader believe that the English or "Ingliz" are friends of Morocco. The number of these travellers is rather high: 
the first of whom is Britain's Representative Plenipotentiary in Morocco, John Drummond Hay (1845-1886). In addition to him, there are Phillip Durham Trotter, Robert Bontine Cunninghame Graham, Frances Macnab, Arthur Leared and Budgett Meakin, inter alia. ${ }^{1}$

The two less-examined British traveller-writers, Leared and Meakin, made their peregrinations into a Precolonial Morocco which had begun to witness a slow precipitous decline into anarchy and loss of independence mainly since 1856 which marked the signing of the Anglo-Moroccan "Convention of Commerce and Friendship" under the auspices of John Drummond Hay. Doctor Arthur Leared was born in 1822 in Dublin. He travelled to India and other far-eastern countries. He headed towards Morocco as a far-off destination after his health worsened. The Moorish space was for Leared a fantastic refuge for his health problems, "One thing held in view has been to bring into notice, as much as possible, the incomprehensible climates to be found in Morocco for persons suffering from affections of the chest" (Leared vi). In 1872, Leared journeyed to Morocco, and he revisited the country on two other occasions; in 1877 as physician to the Portuguese Embassy, and in the summer of 1879 . A free pass from the sultan, Moulay Hassan I (r. 1873-1894), enabled him to visit different cities of Morocco: Tangier, Casablanca, Azemmour, Mazagan, Mogador, Saffi, Mequinez, Marrakesh) and Fez. During his journey, he shed light upon the Barbary state, its government, military power, religion, education, natural history, agriculture, language and cultural markers and the mores of its people. The result of his first two journeys was the publication of a very valuable book entitled Morocco and the Moors (1876).

Roughly, ten years later - at the end of the 1880s - Budgett Meakin joined his father, Mr. Edward E. Meakin, who settled in Tangier in 1884 and founded the first English newspaper in Morocco, The Times of Morocco. At first, the paper was published monthly, and then, from 1886, on a weekly basis. Meakin started to work on the paper as assistant editor, and from 1888 as the paper's editor (Meakin, The Moorish Empire 535). Meakin studied spoken Moroccan Arabic, and became, in fact, a historian of Morocco and Moroccans. He journeyed among the Moors, and he managed to interact with them easily. He also adopted native attire and chose a native name; he called himself Tahar Ben Mikki (Meakin, The Moors 2). In 1895, he returned to England, but his requests for funding his research were rejected, so he decided to go by himself to Morocco for one year, and then travelled another year in other countries such as Uzbekistan and Iraq, and further east, to Japan. He returned to England once more in 1897 in order to write and edit his books. 
He published four comprehensive travel and history books about Morocco, which established his status as the leading authority in this field: The Moorish Empire (1899), The Land of the Moors (1901), The Moors (1902) and Life in Morocco and Glimpses Beyond (1905). ${ }^{2}$

This paper will dwell on the trope of alterity as an umbrella term and on the way Arthur Leared and Budgett Meakin deploy different representational strategies in their interactions with the Moors in Western Barbary. That is, I shall explore the rhetorical strategies, and the representations of the other, typically offered by travel writing when it is in the service of empire and whenever it is informed by imperialist attitudes and ideologies. In these two precolonial travel texts on Morocco, cultural difference is more predicated on a binary and Manichean structure that sets a polarity in which the Self and the Other are pitted against each other. In addition to this aspect of allegory of binarism, exoticization and temporal distanciation or allochronic distancing are two other conspicuous rhetorical strategies and processes of alterity that will be approached in these two travelogues.

\section{Alterity}

As a term that has acquired considerable value in contemporary critical and social theory since the 1980 os, alterity is virtually used interchangeably with "otherness". Popularized in the work of the French philosopher Emmanuel Levinas in the 1970s, it originally meant a sense of the non-self, of something that is outside of, and therefore different from, the self. Alterity "is what enables us to distinguish ourselves from the world, to see the world as outside us and our consciousness" (Nayar 6). In postcolonial theory, this umbrella term is "derived from the Latin alteritas, meaning 'the state of being other or different'. Its English derivatives are alternate, alternative, alternation, and alter ego" (Ashcroft et al. 171). In this realm, the first coinage of the concept of othering is Gayatri Spivak, one of the pillars of postcolonial theory; she uses it to refer to the process by which imperial discourse creates its others. Othering describes the various ways in which colonial discourse produces its subjects. In Spivak's explanation, "othering is a dialectical process because the colonizing Other is established at the same time as its colonised others are produced as subjects" (Ashcroft 11). It is only relatively recently that cultural historians have become interested in the idea of the "Other", with a capital $O$ - or perhaps with a capital $A$, since it was the French theorists who led the 
way in discussions of l'Autre. Spivak stresses the interdependence of the Self and the Other as the construction of the one is extremely related to the other, and as the other is regarded as the reflection of the self.

The traditional reading of travel literature focuses mainly on the entertaining aspects of the genre. Yet, the coming of postcolonial theory as an intellectual project and its reading of these interactions sees it as the representation of the Self outside the limits and restrictions of its own culture. The representation of the Self through the Other is necessary, so without the investigation into the Self, the study of the Other would be incomplete because of the dialectical relationship between these binary constructs, the traveller/observer on one hand and the travellee/the observed on the other. Any traveller possesses the desire to make a comparison or an analogy with the other. This is an aspect which characterizes most discourses that attempt to go beyond their precinct and invade and encounter with what is exotic, foreign, eerie and mysterious about the other. This desire can be articulated and materialized in the representation of the other "there" for the "Self" "here". Put otherwise, the absence/presence dichotomy is what features in most discourses about the other. Expatiating upon the process of othering, Johannes Fabian notes

[t]his would help us to realise that our ways of making the Other are ways of making ourselves. The need to go there (to exotic places, be they far away or around the corner) is really our desire to be here (to find or defend our position in the world). The urge to write ethnography is about making the then into a now. In this move from then to now the making of knowledge out of experience occurs. Both movements, from here to there and from then to now, converge in what I called presence. This is the way I would define the process of othering. (Fabian $75^{6}$, emphasis in original)

In the same line of argument, Mary Louise Pratt has clearly defined this way of othering. In periods of imperialism, "Othering" is one of the ways in which the conquering nation organizes thoughts and actions towards the colonized nation, but each colonial context develops a specific range of colonialist discourses dependent on the type and length of colonial relations. Pratt asserts that "Othering" is achieved through language choices, which means that the other is linguistically and textually created:

The people to be othered are homogenised into a collective 'they', which is distilled even further into an iconic 'he' (the standardized adult male 
specimen). This abstracted 'he'/'they' is the subject of verbs in a timeless present tense, which characterizes anything 'he' is or does, not as a particular historical event but as an instance of a pregiven custom or trait. (120)

\section{The Binary Allegory in Leared's and Meakin's Travelogues}

Leared and Meakin conceive of otherness in binary terms; they have the tendency to dichotomize "human reality" into us/them, black/white, Occident/ Orient, etc. So, this founds the power relation between the subject and the object upon a binary basis wherein the object is subjected to all types of supremacist and condescending attitudes. In Leared's Morocco and the Moors and in Meakin's Life in Morocco, the modes of representation they elaborate for the portrayal of the Moroccans attest to the structuring function of this binary structure, which must not be wholly assigned to the colonial situation in which the opposition between the self and the other is well established because of the differences of race, religion, colour, language and space, etc.

The processes by which notions of the self and other are defined, articulated and negotiated are a crucial part of what might be thought of as the cultural dimension of colonialism. The nineteenth-century imperial project most clearly, but not exclusively, depended upon racialized notions of self and other. Imperialism operated within an ideal of the Manichaean binary, which constructed a demonized other against which flattering, and legitimating, images of the metropolitan self were defined. The dominant model of power relations in all colonial societies was the binary opposition/allegory between the putative superiority of the British and the supposed inferiority of the Moors/the Orientals. This axis in turn provides the central feature of the colonialist cognitive framework and colonialist literary representation. In this context, one of the main subterfuges on which colonialist discourse feeds is the deployment of binary oppositions, or what Abdul JanMohamed dubs "the Manichean allegory"; that is, "a field of diverse yet inter-changeable oppositions between white and black, good and evil, superiority and inferiority, civilization and savagery, intelligence and emotion, rationality and sensuality, self and Other, subject and object" (63). Travel literature "amounts to a system of dichotomies, mechanical in its Manichaeism; the real dialectical relation of European ethnocentrism with Barbary's unflattering 'character' in time 
resolves itself into an open advocacy of imperial domination" (Ben Rejeb $346)$.

Leared and Meakin virtually assign some qualities to the individual "savage" such as superstition. For instance, Leared dehumanizes the Moors and perceives them as a people who are in the grip of irrational fear, despotism and superstition, which is a rhetorical strategy that travel writers often use to dehumanize and stigmatize communities they find threatening and incomprehensible. To exemplify, for Leared, "there is no end to the superstition of the Moors, or rather the people of Morocco; for the people as a whole appear to be infected. Witchcraft is generally believed in, and its rites are largely predicted" (271-272). It should be noted that these rhetorical strategies are also characteristic of colonial discourse more generally, and so may be found in other genres besides travel writing, such as fiction, journalism, imperial administration and visual art (Spurr 4), whenever those genres are informed by imperialist attitudes and ideologies. Leared and Meakin espouse an unabashed imperialism, seeing it as the natural order of things that white peoples of European extraction should govern vast tracts of the globe. Such ethnocentric assumptions produced, and were simultaneously a product of, a pervasive imagery and ideology of, empire that found expression at many levels in European society, and in a variety of cultural forms.

Leared and Meakin adopt a pejorative perspective towards Moroccans and their culture, and this standpoint often emanates from a melange of emotions which fluctuates between fear and revulsion (Leared 55, 56, 225, 267, 268; Meakin V, 57, 151). This feeling, which had been circulated among a group of travellers-cum-traders to Morocco since the onset of the modern age, is attributed to some extent to "Barbary Piracy" and the corsairs' activities in the Mediterranean world. According to Daniel Panzac, "from the beginning of the sixteenth century to the first decades of the nineteenth century, the Barbary corsairs struck fear into the hearts of the occupants of the Northern coasts of the Mediterranean and plagued European imagination" (1). For Lotfi Ben Rajeb, Barbary discourse routinely overlooked Western agency while it reduced North Africa to no more than a group of piratical states that had managed to live off the spoils of plunder and Christian slavery for centuries (20). ${ }^{3}$ In this vein, the Mediterranean basin was decisive in imprinting an ineffaceable image of the Moors because it was in this region that large numbers of Britons were taken captive by "Salé Rovers" and privateers. The spread of captivity accounts in the seventeenth and eighteenth centuries is evidential. It was the 
captivity narrative, "buttressed by sermons about returning Englishmen who had converted to Islam during captivity, which held the public imagination, and shaped the way generations of English men and women thought about Muslims and the Islamic world" (Maclean and Matar 124).4

Very often, still, instances of pejorative "othering" in travel writing serve an important justificatory function. The traveller's portrayal of another culture is sometimes ideologically motivated, seeking at some level to justify and encourage a particular policy towards those others. The ideological dimensions of travel writing, and the larger rhetorical purposes served by the frequent tendency of travel writers to depict other groups and cultures in a hostile or condescending way, are topics that have been much addressed in the recent wave of travel writing studies. There is a comparison and distinction between these travel writers, who are representatives of a supposed civilization, on the one hand, and the Moors who are thus made to seem "savage" and "uncivilized", on the other. They narrativize the other in a sense that reinforces a range of prejudicial and ethnocentric attitudes.

This negative "othering" has generally served ideological ends, and has often been used to endorse the British colonial ambition in the region. Leared deploys a number of tropes characteristic both of colonial discourse in its most extreme form, and also accounts in which another culture is "othered" in an especially hostile manner; for example, he portrays the Moors as recalcitrant and arrogant, a type of arrogance which is dyed with ignorance: "arrogance, the invariable sign and accompaniment of ignorance, is a prominent characteristic of the Moor. He believes himself and his nation to be superior to all the world. He recognizes the inventions and improvements made by Europeans, but it is the recognition of disdain" (222-223). Likewise, Meakin writes: "the greatest obstacle to progress in Morocco is the blind prejudice of ignorance. It is hard for the Moors to realize that their presumed hereditary foes can wish them well, and it is suspicion, rather than hostility, which induces them to crawl within their shell and ask to be left alone" (46). Leared represents and essentializes the Moors patronizingly by attributing cruelty to them as an obvious feature deeply inherent in their nature:

The Moorish nature is cruel and insensible to suffering not personally experienced. The tortures inflicted by those in power in the name of law, but frequently out of revenge, or to extract money will be refused hereafter. The Moors do not even confound how anyone can be interested in the sufferings of the lower animals. (Leared 224) 
Leared's and Meakin's travel accounts permeate with colonial discourse of improvement and reform as well as of rescuing the "native". In improving the latter, the two travellers were being given a chance to improve (and prove) themselves as humanitarian individuals. Rooted in the Victorian culture of character building, work ethic, and self-improvement, the colonial discourse of reform was as much about improving English character through the actions of such sterling individuals as it was about improving the natives. The civilizing mission therefore established the moral superiority of Britain as it was a mode of self-fashioning and self-legitimization because it put the English, the humanitarian leaders of the world, in the foreground.

Meakin's account of the sufferings of slaves in Morocco and of those who seek protection from the British consuls and protégés can be seen as an instance of this discourse of improvement and reform and as a ploy for potential colonial intervention. In his chapter entitled "The Protection System", Meakin adeptly represents the Moroccans who seek "refuge", "protection" and "peace" because the British proffer them all these. The Moors lack the ability to take action and what they do is determined by the ways in which their identity has been constructed. Moroccans are in need of the colonial agency to be summoned. To quote Meakin: "Crouched at the foreigner's feet lay what appeared but a bundle of rags, in reality a suppliant Moor, once a man of wealth and position. Hugging a pot of butter brought as an offering, clutching convulsively at the leg of the chair, his furrowed face bespoke past suffering and present earnestness" (242).

The Other/the Moor is reified and reduced to a degree of nullity; the Moor is rendered as a "bundle of rags". This other is shorn of his subjectivity and selfhood; he is dramatized in a vein that calls for the intervention of the soonto-be colonizer. The Moors are perceived as inhabiting the cusp of prehistory and imperial modernity is personified in their adjacent neighbour, Algeria. To emphasize this convention, Meakin draws a comparison between Morocco, a state on the verge of colonialism, and Algeria, an already occupied country (by the French in 1830):

A journey through Algeria shows what a stable and enlightened Government has been able to do in a land by no means so highly favoured by Nature as Morocco, and peopled by races on the whole inferior. The far greater proportion of land there under cultivation emphasizes the backward state of Morocco, although much of it still remains untouched; while the superior quality of the produce, especially of the fruits, shows what might 
be accomplished in the adjoining country were its condition improved. (Meakin 307)

The protégé system emphasizes the fact that the traveller and Europeans in general are actors; they have power, whereas the Moor/the Other is powerless and enacted upon. To quote Meakin, "Fortunately, the Moorish cause has some champions. For many years she has been dumb. Now, however, that she is assailed, we find a small but influential band of writers coming forward with pens to do battle for her" ( 383 , emphasis added). The presence of the Moors is debunked, and the omnipresence and omniscience of the colonial agency is elucidated and perpetuated to put the self in a privileged and superior position. Meakin is a master-player in complete command of his narrative puppets. He devotes a whole chapter to dealing with the French Protectorate in Morocco and its "advantages" to Moroccans who live in drastic circumstances.

The notion of the "Protectorate" is contrived for the purpose of colonialism. Thus, the protectorate system joined other forms of nineteenth century imperial culture, whose ideology was based, in the words of Edward Said, on "notions that certain territories and people require and beseech domination" (9). Meakin subsumes in his travel text a set of dialogues between the Moors who seek protection and British consuls and merchants. Meakin records the Moorish merchant's strong tendency to be protected by these consuls and officials" "humanitarian" relief to achieve his goal: to persuade the reader that the protectorate system is an urgent key. As an instance, a Moorish merchant begs "O Bashador, if once I were under thy protection" (246), and the latter wishes he were under the protection of Christians:

Wonderest thou still, O Bashador, that I prefer the Nazarenes, and wish there were more of them in the country? I respect the dust off their shoes more than a whole nation of miscalled Muslims who could treat me as I have been treated; but God is just, and 'there is neither force nor power save in God yes, 'all is written'. He gives to men according to their hearts. We had bad hearts, and he gave us a Government like them. (146)

Leared and Meakin consider themselves as the saviours of humanity from all aspects of sufferings and ordeals and as members of a people who confer help and assistance to helpless people like the Moors. Reforms and rescue fed 
into a larger colonial project of domination but also served a more insidious purpose: that of self-fashioning and self-legitimization. The discourse of the civilizing mission thus furthered the image-making of the British statesman as a morally upright, selfless humanitarian who was the moral superior for the world to follow.

\section{Exoticization}

Many travellers at the end of the nineteenth century, especially with the spread of the fin de siècle malaise and the complete change of the Victorian perception of values and traditions, headed for the Orient, and they bore in mind one primary motive: to look for the exotic among the Orientals (Behdad 1994). Victor Segalen's definition of exoticism as the "aesthetics of diversity" is appropriate to a travel narrative that frequently depoliticizes the objects of its study and practically seeks to capitalize on anesthetized myths of cultural difference. Leared and Meakin undertake the Orientalist exoticist project, and an exoticist desire for the disappearing other. This desire is deeply rooted in the Orientalist tradition, a desire which Nerval calls " $L e$ désir de l'Orient". Leared and Meakin resort to the rhetoric of exoticization as a mode of representation and as a process of identification of alterity that is deeply seated in colonial discourse. These travellers find it difficult to get rid of an authority that contributes to their shaping of a specific vision about the Orient, but at the same time they try to produce a new discourse of the other that is exotic.

The purpose behind the description of religious sects by Leared and Meakin is to illuminate the exotic aspect of the Moorish culture; sometimes there is exoticization, as within such method of exoticizing the other is othered and represented in a strange and primitive manner, needing the intervention of the white man to rescue the other from all superstitious beliefs. In a chapter entitled "Education-Religion-Superstitions-the Healing Art", Leared describes the exotic spectacle of the Aissawa $a^{5}$ ceremonies. For Leared, these ceremonies reflect "the eccentricities of Mohammedanism":

While the mad dance is still proceeding, a sudden rush is made from the sanctuary, and the dancers, like men delirious, speed away to a place where live goats are tethered in readiness. At sight of these animals the fury of the 
savage and excited crow reaches its height. In a few minutes the wretched animals are cut, or rather torn to pieces, and an orgy takes place over the raw and quivering flesh. (Leared 268)

The mysterious and the eerie beheld in exotic peoples, as Stephen Greenblatt demonstrates in his book on New World conquest, Marvelous Possessions: The Wonder of the New World, may precede their violent subjugation and colonialism; the exotic splendour of newly colonized lands may disguise the brutal circumstances of their gain. To exemplify, in his description of the spectacle of the Aissawa, Leared observes that "words can do no justice to the frightful scene which now ensures. The naked savages ... with their long black hair, ordinarily worn in plaits, tossed about by the rapid to-and-from movements of the head, with faces and hands reeking with blood, and uttering loud cries resembling the bleating of goats, again enter the town" (269).

In Leared's and Meakin's travel texts, there is the exoticization of the Moors, the purpose of which is to downplay them and their culture and to bring to the fore the idea of the Moors' urgent need of civilizing mission. For Leared, the Moors' religion, Islam, is tainted with "eccentric" ceremonies and customs which perpetuate their primitivism and fanaticism. Apparently, these scenes seem exotic, but the author portrays them from a patronizingly superior standpoint. In his description of another scene of the Aissawa, Leared observes that

Snakes are also thrown to them as tests of their divine frenzy, and these share the fate of the goats. Sometimes a luckless dog, straying as dogs will stray in a tumult, is seized on. Then the laymen, should any be at hand, will try to prevent to prevent the desecration of pious mouths. But the fanatics sometimes prevail, and the unclean animal, abhorred by the Mussulman, is torn in pieces and devoured, or pretended to be devoured, with indiscriminating rage. (269)

After describing the Aissawa sect, Leared moves on to represent another sect: Hamadachas. ${ }^{6}$ The author stands aghast at all the instruments seized by Hamadachas that consist of "choppers, clubs thickly studded with large nails, small cannon balls, and iron rings which have five or six short thick sticks attached by one end to the ring. With these instruments they literally cut and thrash themselves as they walk along till they are covered with blood" (Leared 270). 
In the same vein, Budgett Meakin renders the snake-charmer as the purveyor of the exotica through narrativized scenes: "This is the man from whom to learn of love and fighting, of beautiful women and hairbreadth escapes, the whole on the model of the 'Thousand Nights and a Night', of which versions more or less recognizable may now and again be heard from his lips" (Meakin 139). The exoticist rhetoric upon which these travellers depend to represent the fetishized otherness "masks the inequality of the power relations without which discourse could not function" (Huggan 14). This mode of exoticism was entirely committed to spatializing territories into fixed, static, and unchanging landscapes that existed in temporalities outside of modernity: vast, ethnographic museums of alien cultures and peoples who lived in a zone of contemporary non-contemporaneousness that would soon disappear before the homogenizing machine of industrial capitalism.

\section{Moroccans as "Anachronistic Humans"}

In their travelogues, Arthur Leared and Budgett Meakin arguably and inevitably engage in the process of othering through which they hold with different degrees a patronizing and condescending stance. They adopt a temporal and allochronic discourse through which Moroccans are denied coevalness and placed in a historical calendar that is at the bottom of human development. Indeed, as Fabian states, "[t] he history of our discipline [anthropology] reveals that such use of Time almost invariably is made for the purpose of distancing those who are observed from the Time of the observer" (25). Western, and mainly British, travellers can position themselves as the emissaries of modernity and progress, and so implicitly claim superiority over the others they depict. This impression is heightened by the frequent deployment of what is known as "ethnographic present" (Thompson 147).

The concept of time is part of the value of travel and it is obvious in the way it functions as a process of spacio-temporal "distancing" implemented by the subject/the observer over the object of study/the observed. In the same context, "time is the carrier of significance, a form through which we define the content of relations between the Self and the other" (Fabian ix). Moroccans are "marooned" in a temporal mould. By so doing, these two travellers under analysis want to perpetuate their superiority and power and to essentialize Moroccans and cast them in a homogenizing discourse on the one hand, and to journey backward in time to an anachronistic moment of prehistory, 
on the other. In this vein, "geographical difference across space is figured as a historical difference across time" (McClintock 40, emphasis in original).

Leared and Meakin began their journey mostly from London, the hub of civilization, capitalism, modernity and enlightenment. In this respect, the inhabitants of the peripherical places or the "edge of empire" "were assigned a place "elsewhere" in the "first in Europe and then elsewhere" structure of time" (Chakrabartry 8). Thus there occurs in these two travelogues, and in many western depictions of the other more generally, what Johannes Fabian has termed a "denial of coevalness" or an act of "allochronism" (Fabian 3137). That is to say, many Western travellers take it for granted that it is only they and their compatriots who are properly modern, and another nation by textual means is denigrated and denied inter-subjective time and social contemporaneity. What's more, the "others" that they encounter, willy-nilly, are frequently regarded almost as living fossils, and as being to a greater or lesser degree survivors from an earlier epoch. Hence, there is the frequent conflation of geographical and temporal distance in many Western travelogues as travellers venture to some remote or unfamiliar region and simultaneously present themselves as going back in time. By implicitly or explicitly denying "coevalness", however, Leared and Meakin can position themselves as the purveyors of modernity and progress, and so subtly claim superiority over the others they describe. The "denial of coevalness" is, therefore, the denial of otherness in the Levinasian sense. This technique is accomplished through a whole series of methods and techniques such as unilateral observation of the "natives"; classification of their habits and practices; taxonomic descriptions; uses of maps, charts, tables to visualize the Other's culture, etc.

Leared's and Meakin's travelogues abound with words of temporal aspects such as "primitive", "asleep", "degeneration", "inertia", "passiveness", inter alia, to shed light upon Moroccans as a people that are at a lower grade and as an Other that needs urgent tutelage and protection on the one hand, and colonization on the other to be salvaged from pitiful conditions. As an instance, Arthur Leared observes that

A little circumstance occurred during one of my visits, the narration of which will illustrate the oriental apathy here. Though so simple, I could scarcely contain my gravity. While conversing with a lady, I observed that her eyes, which were inflamed, attracted to them a number of troublesome flies. One in particular so posted itself that it could stoop over and thrust its proboscis between the lids at the inside corner of one eye. Each time 
this was done, the lady merely shut her eye with a jerk, instead of using her hand to sweep off the pest. The fly, as impassive as his victim, merely backed a little, withdrew his sucking tube for an instant, and then began again. In small things, as in more important matters, passiveness was the rule. (131-132, emphasis added)

Moreover, Meakin declares in the first part of his travelogue that Morocco is the only country in Barbary that was not under the Ottoman regencies before the coming of the French in contrast to its neighbours like Algeria, Tunisia and Tripoli (Libya). So, it remained unchanged and primitive:

Morocco, of all the North African kingdoms, has always maintained its independence, and in spite of changes all round, continues to live its own picturesque life. Picturesque it certainly is, with its flowing costumes and primitive homes, both of which vary in style from district to district, but all of which seem as though they must have been unchanged for thousands ofyears. (Meakin 2, emphasis added).

In this excerpt, we are dealing with an essentializing, iconographic discourse that has been constructing types and stereotypes as perennial symbols, which are made static and unchanging. This illustration is a good indication that shows the ability of travel discourse to create a simulacrum as an artistic expression that fixes a moment in history (Rouwane 152). The words deployed in the above citation have the goal of stressing the fact that countries and lands that were exposed to foreign occupation regardless of its nature had witnessed change and improvement. Here, through the journey of the traveller in Algeria, the author makes a clear comparison between Algeria, an adjacent country and an already colonized country which France occupied in 1830, and Morocco, "a journey through Algeria shows what a stable and enlightened Government has been able to do in a land by no means so highly favoured by Nature as Morocco, and peopled by races on the whole inferior" (Meakin 307). Implicit in this interpretation is that change came about under the aegis of the French protectorate; Algeria is more "enlightened" and developed than Morocco, Meakin claims, and this "progress" is attributed to the French intervention in it and its civilizing missions; the Ottoman regency in Algeria did not add anything because for the traveller the Turks are Orientals and they are decadent, villainous and as backward as the Moors: 
The Turks are such an inferior race to the Berbers and Arabs that it is no wonder that they are despised by the natives. They appear much more out of place than do the Europeans, who remain, as in Morocco, a class by themselves. To see a Turk side by side with a white-robed native at prayer in a mosque is too ridiculous, and to see him eating like a wild man of the woods! Even the governor, a benign old gentleman, looked very undignified in his shabby European surroundings, after the important appearance of the Moorish functionaries in their flowing robes. (Meakin $326-327)$

Throughout his travelogue, Meakin consigns the other nation to a time-scale which is unchanging: "Far from being "poor rejected Moors who raised our childish fears" the people of Morocco consist of fine, open races, capable of anything, but literally rotting in one of the finest countries of the world. The Moorish remains in Spain, as well as the pages of history, testify to the manner in which they once flourished, but to-day their appearance is that of a nation asleep" (14, emphasis added). In this excerpt, the Self (the European) and the Other (the Moor) are dichotomized in a manner wherein the first has recognized his coevalness and the last is denied his. By so doing, these travel writers insist on the premise that Moroccans need to be saved from their state of lethargy and inertia. Their time is obliterated and erased so that power relations would not exist and that the Self continues to have the complete right and authority to represent its Other. Moroccans are denied coevalness to stress this difference between the Self and the Other and dichotomize the two. For Leared, the Moroccans' stagnation is attributed mainly to "the eccentricities of Mohammedanism" (267). This religion, for him, is something of the past, and the more that people cling to it the more stagnant they grow. Leared contends that the Koran is an obstacle to progress. Indeed, Medieval Christian scholarship classified Islam as a heresy, a preconception that perpetuated even later during the Elizabethan and Jacobean eras. These travellers' surveys build up a diatribe on the religion of the Moors partly because of its enslavement of Christians. Barbary as a toponym and its inhabitants as pirates are regarded as an extension of the conflicts of the Crusades; the Moors are the worst type of "Mahometans". 


\section{Conclusion}

With the rise of postcolonial theory, travel writing has acquired a new relevance and prestige as a genre that can trenchantly proffer important insights into the often fraught encounters and interactions taking place between cultures because, most of all, journeys and travels are an encounter, and sometimes a confrontation, with what is usually termed alterity; all travel requires us to negotiate a complex and sometimes unsettling interplay between alterity and identity, difference and similarity. These two travellers identify and highlight the differences between themselves and the members of the Moorish culture. Both travellers deploy dichotomous constructs, different processes, modes and representational strategies by which they depict the other's culture as not only different but also inferior to itself, generating or reinforcing a range of prejudicial and ethnocentric attitudes. Indeed, travel writing as a discourse arguably and inevitably engages in the process of othering through which these travel writers hold, with different degrees, a patronizing and condescending stance. Related to this issue is the process of exoticization which has proved over time to be a tool of imperial power and hegemony. As exoticist imperialists, Leared and Meakin create, differentiate, debase and ultimately vilify the Moorish other, using this process of exoticization as a discursive subterfuge and a mode of representation to perpetuate a set of binary constructs and to spectacularize the cultural difference. Also, there is the adoption of a temporal and allochronic discourse wherein Moroccans are denied coevalness and put in a historical calendar that is at the bottom of human development. The instances of pejorative "othering" in Morocco and the Moors (1876) and Life in Morocco (1905) serve an important justificatory function. They legitimate the travellers' conduct and culture towards the people they met. The travellers' portrayals of the Moors and their topos are often ideologically motivated, seeking at some level to justify Britain's civilizing and humanitarian missions in the "Land of the Moors" and laud imperium and its discursive pomposity. Regardless of the fact that Leared's Morocco and the Moors and Meakin's Life in Morocco do describe and downplay the Moors condescendingly, they do not incite the British imperialist policy-makers to occupy Western Barbary. Moreover, these two writers' premise was that Britain had better continue to allow the imperial nations "friendly" to it - France and Spain, mainly - to carry the burden of occupation and to spread "civilization", and the job of the British was to reap the result of such efforts. 


\section{Notes}

1. See Richard Burton's "Introduction" to Arthur Leared's Morocco and the Moors, viii-ix.

2. Life in Morocco and Glimpses Beyond was published in 1905, a year before the Algeciras Conference (1906) wherein the Moroccan question was deliberated and reforms were pursued under French auspices. The travelogue also appeared one year after the signing of the Franco-British Cambon-Lansdown Declaration, known as the "entente cordiale", in April 1904, which put Moroccan destiny in the hands of France and Spain and allowed Britain to have a free hand in Egypt (Mathews 35-39).

3. When we peruse most of, if not all, the Moroccan envoys to Europe and their accounts from the seventeenth century to the end of the nineteenth century, we find that they dwell upon Al-Andalus with a kind of sorrow and nostalgia: Ahmed bin Qāsim AlHajari (1611-1613), Muhammad ibn 'Abd al- Wahāb al- Ghassānī (169o-1691), Ahmad ibn Mahdī al-Ghazāl (1767), and Mohammed ibn 'Uthmān al-Miknāsī (1779-178o) are the most well-known Moroccan envoys and ambassadors to Europe.

4. These captivity stories and accounts, both bona fide and fictional, were imparted to different sectors of society from king to pauper, and confirmed the hostile stereotypes about this other. Indeed, "stories are at the heart", wrote Edward Said, "of what explorers and novelists say about strange regions of the world" (xii).

5. Aissawa are members of a religious sect. They adhere to the teachings of the saint Sidi Ben Aissa, whose tomb is at Meknes. For Leared, "this holy man ... is said to have cast himself from the top of a high tower, and to have fallen without injury" (267), so his followers believe in their invulnerability to physical injury. See also Walter Harris's Morocco That Was, 285-286.

6. Hamadachas are followers of Sidi Ali ben Hamdouch, who is buried on the slopes of the Zarhoun Mountains, near Meknes.

7. "Coevalness" combines the meanings of both simultaneity and contemporaneity. Fabian relates it to the German term Gleichzeitigkeit; he adds that "it is to connote a common, active, 'occupation', or sharing, of time." Coevalness is closely related to "intersubjective time" which has its philosophical sources in phenomenological thought and connects to the "communicative nature of human action and interaction" (24).

\section{Works Cited}

Ashcroft, Bill, Gareth Griffiths and Helen Tiffin. Key Concepts in Postcolonial Studies. London: Routledge, 2001. Print.

---. The Empire Writes Back: Theory and Practice in Post-Colonial Literatures. London: Routledge, 1989. Print.

Behdad, Ali. Belated Travelers: Orientalism in the Age of Colonial Dissolution. Durham: Duke University Press, 1994. Print.

Ben Rejeb, Lotfi. "Barbary's 'Character' in European Letters, 1514-1830: An Ideological Prelude to Colonisation." Dialectical Anthropology. 6. 1982: 345-355. Print.

---. "The General Belief of the World: Barbary as Genre and Discourse in 
Mediterranean History." European Review of History: Revue européenne d'histoire. Vol 19 No. 1. 2012: 15-31. Print.

Chakrabartry, Dipesh. Provincializing Europe: Postcolonial Thought and Historical Difference. Princeton: Princeton University Press, 200o. Print.

Fabian, Johannes. "Presence and Representation: The Other and Anthropological Writing." Critical Inquiry. Vol. 16 No. 4. Summer 1990: 753-772. Print.

Harris, Walter B. Morocco That Was. Edinburgh and London: William Blackwood and Sons, 1921. Print.

Huggan, Graham. The Postcolonial Exotic: Marketing the Margins. London: Routledge, 2001. Print.

Greenblatt, Stephen. Marvelous Possessions: The Wonder of the New World. Chicago: The University of Chicago Press, 1991. Print.

JanMohamed, Abdul R. "The Economy of Manichean Allegory: The Function of Difference in Colonialist Literature." Critical Inquiry. Vol. 12 No. 1. Autumn 1985: 59-87. Print.

Leared, Arthur. Morocco and the Moors: Being an Account of Travels, with a General Description of the Country and its People. London: Sampson Low, Marston, Searle \& Rivington, 1876 . Print.

MacClintock, Anne. Imperial Leather: Race, Gender and Sexuality in the Colonized Context. London: Routledge, 1995. Print.

Maclean, Gerald and Nabil Matar. Britain and the Islamic World, 1558-1713. Oxford University Press, 2011. Print.

Mathews, Joseph James. Egypt and the Formation of the Anglo-French Entente of 1904. Philadelphia: University of Pennsylvania Press, 1939. Print.

Meakin, Budgett. Life in Morocco and Glimpses Beyond. New York: E.P. Duton and Company, 1905. Print.

---. The Moors: A Comprehensive Description. London: Swan Sonnenschein \& Co, 1902. Print.

--. The Moorish Empire: A Historical Epitome. London: Swan Sonnenschein \& Co, 1895. Print.

Nayar, Pramod K. The Postcolonial Studies Dictionary. Hoboken: Wiley Blackwell, 2015. Print.

Panzac, Daniel. Barbary Corsairs: The End of a Legend 1800-1820. Trans. Victoria Hobson. Leiden: Brill, 2005. Print.

Pratt, Mary Louise. "Scratches on the Face of the Country, or What Mr. Barrow Saw in the Land of the Bushmen." Race, Writing and Difference. Ed. Henry Louis Gates. Chicago: The University of Chicago Press, 1985. Print. 
Rouwane, M'Barek. "Defamiliarization and the Search for the Exotic in Allochronic Travel Discourse." Middle Ground: Fournal of Literary and Cultural Encounters. No. 4, 2010-2011: 133-163. Print.

Said, Edward. Culture and Imperialism. New York: Vintage Books, 1993. Print.

Segalen, Victor. Essay on Exoticism: An Aesthetics of Diversity. Trans. and Ed. Yael Rachel Schlick. Durham: Durham University Press, 2002. Print.

Spurr, David. The Rhetoric of Empire: Colonial Discourse in Travel Writing and Imperial Administration. Durham: Duke University Press, 1993. Print.

Starr, G.A. "Escape from Barbary: A Seventeenth-Century Genre." The Huntington Library Quarterly. 29. November 1965: 35-52. Print.

Thompson, Carl. Travel Writing. London: Routledge, 2011. Print.

Tiffin, Chris and Alan Lawson, (Eds.). De-Scribing Empire: Postcolonialism and Textuality. London: Routledge, 1994. Print.

Youngs, Tim. The Cambridge Introduction to Travel Writing. Cambridge: Cambridge University Press, 2013. Print.

LAHOUCINE AAMMARI is a high school teacher and PhD researcher, working on British travellers' accounts of Morocco (186os-1930s). He is currently affiliated with the doctoral programme: Interactions in Literature, Culture and Society, University of Sultan Moulay Slimane, Faculty of Arts and Humanities, Beni-Mellal, Morocco. His primary academic research interests are Literary Theory, Literary and Cultural Studies and Travel Narrative. He has published several articles on the latter area of study in peer-reviewed academic journals, including the Prague fournal of English Studies, Romanian Journal of English Studies, English Language Overseas Perspectives and Enquiries and the Athens fournal of Mediterranean Studies.

ammarielho@gmail.com 